Огляди літератури, оригінальні дослідження, погляд на проблему

УДК 616.72-002+616.74-018.38-002]-053.2-036.8-037

DOI 10.11603/1811-2471.2018.v0.i1.8461

\title{
ПРОГНОЗУВАННЯ ВІДДАЛЕНИХ НАСЛІДКІВ ЕНТЕЗИТ-АСОЦІЙОВАНОГО ВАРІАНТА ЮВЕНІЛЬНОГО ІДІОПАТИЧНОГО АРТРИТУ
}

\author{
๑М. Б. Джус', Т. В. Марушко', О. К. Носовець² \\ Національний медичний університет імені О. О. Богомольця, м. Київ ${ }^{1}$ \\ Національний технічний університет України «Київський політехнічний \\ інститут імені Ігоря Сікорського», м. Київ
}

РЕЗЮМЕ. Відомо, що ентезит-асоційований варіант ювенільного ідіопатичного артриту (ЮІА) в ряді випадків може призводити до розвитку значних як позасуглобових, так і суглобових пошкоджень. Переважно уражаються кульшові та колінні суглоби з обмеженням їх функції та розвитком анкілозів, що потребує проведення операційного втручання у цих пацієнтів; також часто розвиваються катаракта та сліпота через ураження очей у дитячому віці.

Мета - оцінити фактори ризику розвитку в дорослому віці суглобових та позасуглобових пошкоджень при ентезит-асоційованому варіанті ЮІА та розробити прогностичну модель їх розвитку.

Матеріал і методи. У дослідження включений 21 дорослий пацієнт з ентезит-асоційованим варіантом ЮІА. Ретроспективно проаналізовано медичну документацію пацієнтів з ентезит-асоційованим варіантом ЮІА, з врахуванням клінічних проявів у дебюті захворювання, лабораторних показників та відповіді на проведену терапію. В дорослому віці для оцінки віддалених наслідків ЮІА використовували інтегральний індекс суглобових (JADI-A) та позасуглобових (JADI-E) уражень.

Результати. Методом бінарної логістичної регресії виявлено фактори несприятливого прогнозу та розроблено математичну модель прогнозування ймовірності виникнення віддалених негативних наслідків ентезитасоційованого ЮІА у вигляді суглобових та позасуглобових уражень.

Висновки. 1. Факторами ризику розвитку суглобових та позасуглобових пошкоджень у дорослому віці в пацієнтів із ентезит-асоційованим варіантом ЮІА $€$ вік пацієнта на початку захворювання, час відтермінування встановлення діагнозу, наявність в дитинстві дактилітів, симетричного артриту, болю в хребті, активність за JADAS в дитинстві, прийом глюкокортикоїдів, потреба в інтенсифікації терапії. 2. Розроблено прогностичну модель розвитку суглобових та позасуглобових пошкоджень у дорослому віці в пацієнтів з ентезит-асоційованим варіантом ЮІА. Заявлений спосіб прогнозування віддалених наслідків ентезит-асоційованого варіанта ЮІА у дорослому віці $є$ ефективним, що дозволяє визначити несприятливий перебіг захворювання та може стати основою до персоніфікованого лікування для запобігання розвитку значних суглобових та позасуглобових пошкоджень внаслідок ЮІА у дорослому віці.

КЛючовІ СЛОВА: ювенільний ідіопатичний артрит; ентезит-асоційований варіант; дорослі; прогноз; віддаленні наслідки; JADI.

Вступ. Ентезит-асоційований артрит - це один з семи варіантів ювенільного ідіопатичного артриту, згідно з класифікацією міжнародної ліги асоціації ревматологів (International League of Associations for Rheumatology - ILAR) [1]. Характерною ознакою цього варіанта $\epsilon$ дебют захворювання у віці старше 6 років. Частіше хворіють хлопчики, а клінічна картина супроводжується наступними ознаками: симетричні артрити великих суглобів, бурсити, гострі іридоцикліти та ентезопатії. У 90 \% хворих виявляють наявність генетичної асоціації з HLA B27 антигеном. У дорослому віці в таких хворих часто розвиваються сакроілеїт та спондилоартропатії. За ILAR критеріями включення цього варіанта артриту $\epsilon$ артрит і ентезити, або артрит, або ентезит із такими двома ознаками:

а) чутливість сакроілеальних з'єднань i/a6о запальний біль у спині;

6) наявність HLA B27;

в) початок артриту в хлопчиків після 6 років;

г) гострий (симптоматичний) передній увеїт; д) анамнестичні дані про анкілозивний спондиліт, ентезит-асоційований артрит, сакроілеїт із запальними захворюваннями кишечника, синдром Рейтера, або гострий передній увеїт у осіб першого ступеня спорідненості.

Критеріями виключення ентезит-асоційованого артриту $\epsilon$ :

1) псоріаз або сімейний псоріаз у осіб першого ступеня спорідненості;

2) позитивний ревматоїдний фактор (IgM) щонайменше двічі впродовж 3 місяців;

3) наявність проявів системного ЮІА.

Оскільки при цьому варіанті артриту вражаються не лише великі суглоби та хребет, а наявні й позасуглобові ураження у вигляді іридоциклітів та увеїтів, важливим $\epsilon$ вивчення віддалених суглобових та позасуглобових наслідків ентезит-асоційованого варіанта ЮІА в дорослому віці.

Мета - оцінити фактори ризику розвитку в дорослому віці суглобових та позасуглобових ушкоджень при ентезит-асоційованому варіанті 
Огляди літератури, оригінальні дослідження, погляд на проблему

ЮІА та розробити прогностичну модель їх розвитку.

Матеріал і методи дослідження. В дослідження були включені дані 21 дорослого пацієнта з ентезит-асоційованим варіантом ЮІА. В цю групу ввійшли хворі з різних регіонів України, яким було встановлено діагноз ЮІА в період між 1984 та 2014 роками.

Критеріями включення були вік старше 18 років, наявність діагнозу ЮІА за класифікацією ILAR. У дослідження не включали пацієнтів з тривалістю захворювання менше 3 років.

Усі пацієнти були обстежені амбулаторно або стаціонарно на базі Олександрівської міської клінічної лікарні м. Київ у період між квітнем 2015 та березнем 2017 р. У хворих з ентезит-асоційованим варіантом ЮІА оцінювали активність захворювання за JADAS та DAS28, функціональний стан за шкалою HAQ. Для оцінки віддалених наслідків ЮІА використовували інтегральний індекс суглобових (JADI-A) та позасуглобових (JADI-E) уражень [2]. Крім того, ретроспективно проаналізовано медичну документацію пацієнтів з ентезитасоційованим варіантом ЮІА, а саме - вік дебюту захворювання, час відтермінування встановлення діагнозу, активність захворювання в дебюті за шкалою JADAS, тривалість ранкової скутості в дебюті захворювання, клінічні прояви, характер суглобового синдрому та системних уражень (в тому числі наявність увеїту, висипки, лихоманки, лімфоаденопатії), наявність ревматоїдного фактора, антитіл до циклічного цитрулінового пептиду, HLA-B27 антигену, антинуклеарного фактора, рівень ШОЕ та СРБ в дебюті захворювання та на тлі лікування, оцінки загального стану пацієнтом та лікарем в дебюті захворювання за візуальною аналоговою шкалою (ВАШ), проведене медикаментозне лікування з урахуванням наявності чи відсутності глюкокортикоїдної терапії (ГК), базисної терапії протиревматичними хворобомодифікуючими препаратами (БПРП) та імунобіологічної терапії (IБT) і потреби в інтенсифікації лікування.

Статистичний аналіз проводили за допомогою методів описової статистики та шляхом розрахунку показників відношення шансів. Дані представлені як середнє \pm стандартне відхилення (SD) для безперервних змінних у випадку нормального розподілу даних та медіана (25\% квартиль; 75 \% квартиль) у протилежному випадку. Перевірку розподілу даних проводили за допомогою непараметричного критерію Колмогорова-Смірнова. Для порівняння груп досліджених за кількісними ознаками використано критерії Стьюдента та Манна-Уітні, для якісних - критерій $\chi^{2}$ Пірсона. Розрахунок показників відношення шансів і довірчого інтервалу (95 \% ДІ) проведено для випадків, коли незалежна змінна $\epsilon$ бінарною, і для випадків, коли незалежна змінна $\epsilon$ кількісною (безперервною). Для кількісних змінних використана оцінка Мантеля-Хензеля, яка являє собою скориговане відношення шансів і дозволяє отримати оцінку значущості ознаки для подібного типу даних. Для розрахунку коефіцієнтів моделі на основі відібраних показників застосовано метод бінарної логістичної регресії. Модель має вигляд:

$$
p=\frac{1}{1+\exp (-y)}
$$

де $p$ - ймовірність настання прогнозованої події, а

$$
y=a_{n} x_{n}+a_{n-1} x_{n-1}+\ldots+a_{0}
$$

- величина, яка інтегрально характеризує ступінь впливу прогностично значущих факторів $x_{1}, \ldots+x_{n}$ на ймовірність $p$ виникнення прогнозованої події.

Статистично значимим вважали значення імовірності $p<0,05$. При аналізі використовували пакет для статистичної обробки даних IBM SPSS Statistics 21.0.

Результати й обговорення. У групу обстежених хворих увійшли 3 жінки (14,3 \%) та 18 (85,7 \%) чоловіків, середній вік на момент огляду становив $(22,2 \pm 3,8)$ роки. Середній вік початку захворювання становив $(13,8 \pm 2,2)$ років, а середня тривалість захворювання на момент огляду $-(5,8 \pm 3,4)$ років. Медіана відтермінування діагнозу, тобто затримка у встановленні діагнозу, становила 4,0 міс. (від 1 до 16 міс.).

Серед обстежених дорослих пацієнтів з ЮІА у 6 (28,6 \%) виявлено розвиток суглобових пошкоджень та у 5 (23,8 \%) - позасуглобових, що, за інтегральними показниками віддалених наслідків оліартикулярного варіанта ЮІА, відповідало JADI-A - $(0,4 \pm 0,9)$ (від 0 до 4) та JADI-E - $(0,3 \pm 0,6)$ (від 0 до 2).

3 метою визначення факторів ризику несприятливого прогнозу та розвитку негативних пошкоджень при ентезит-асоційованому варіанті ЮІА всі пацієнти були поділені відповідно до наявності суглобових та позасуглобових пошкоджень у дорослому віці (табл. 1). Відсутність суглобових пошкоджень виявлено у 15 хворих (71,4 \%), а позасуглобових -у 16 пацієнтів $(76,2 \%)$. Встановлено, що в пацієнтів із суглобовими та позасуглобовими пошкодженнями захворювання дебютувало в молодшому віці, порівняно з пацієнтами без таких пошкоджень. Важливо, що в середньому діагноз був встановлений через 24 місяці (Ме 5; 63) після початку перших клінічних проявів ЮІА у пацієнтів з суглобовими пошко- 
Огляди літератури, оригінальні дослідження, погляд на проблему

дженнями, на відміну від 3,5 місяців $($ Ме 1,$7 ; 18)$ у пацієнтів без розвитку суглобових пошкоджень $(p<0,05)$. Позасуглобові пошкодження також частіше розвивалися у тих пацієнтів, в яких була за- тримка встановлення діагнозу до 48 (Ме 15,7; 69) місяців $(p<0,05)$. Виявлено, що на формування віддалених наслідків не впливають ні стать паці-

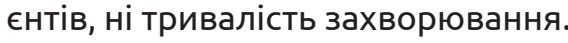

Таблиця 1. Загальна клінічна характеристика пацієнтів з ентезит-асоційованим варіантом ЮІА

\begin{tabular}{|c|c|c|c|c|c|c|}
\hline \multirow[b]{2}{*}{ Показники } & \multicolumn{3}{|c|}{ Суглобові пошкодження } & \multicolumn{3}{|c|}{ Позасуглобові пошкодження } \\
\hline & $\begin{array}{l}\text { відсутні } \\
(n=15)\end{array}$ & $\begin{array}{c}\text { JADI-A } \geq 1 \\
(n=6)\end{array}$ & $\mathrm{p}$ & відсутні (n=16) & $J A D I-E \geq 1(n=5)$ & $\mathrm{p}$ \\
\hline Стать (ж/ч) & $\begin{array}{c}3(20 \%) \\
/ 12(80 \%)\end{array}$ & $\begin{array}{c}0(0 \%) \\
/ 6(100 \%)\end{array}$ & $>0,05$ & $\begin{array}{c}2(12,5 \%) / 14 \\
(87,5 \%)\end{array}$ & $\begin{array}{c}1(20 \%) / 4 \text { (80 } \\
\%)\end{array}$ & $>0,05$ \\
\hline Вік на момент початку захворювання & $14,2 \pm 17,7$ & $13,0 \pm 3,2$ & $<0,05$ & $14,3 \pm 1,7$ & $12,4 \pm 3,3$ & $<0,05$ \\
\hline Час відтермінування діагнозу (міс.) & $\begin{array}{c}3,5 \\
(1,7 ; 18)\end{array}$ & $\begin{array}{c}24 \\
(5 ; 63)\end{array}$ & $<0,05$ & $3,5(2 ; 12)$ & $\begin{array}{c}48 \\
(15,7 ; 69)\end{array}$ & $<0,05$ \\
\hline Тривалість захворювання, роки & $4(3 ; 7)$ & $6(4 ; 11)$ & $>0,05$ & $4(4 ; 6,7)$ & $8(3 ; 13)$ & $>0,05$ \\
\hline
\end{tabular}

Аналізуючи клінічні прояви у пацієнтів з ентезит-асоційованим варіантом ЮІА в дитячому віці (табл. 2) ми виявили, що в пацієнтів, в яких в дебюті була більш виражена клінічна картина з наявністю лихоманки, дактилітів та з високою активністю за JADAS, рідше спостерігали віддалені суглобові наслідки, що можна пояснити частішим призначенням їм протизапальної імунодепресивної терапії (табл. 4) у вигляді ГК $(p<0,05)$, тоді як позасуглобові пошкодження частіше розвивалися у пацієнтів з наявністю в дебюті артри- ту більше трьох суглобів, симетричного артриту, болю в хребті, в т.ч. у шийному його відділі, та ентезитів.

При аналізі лабораторних (табл. 3) показників у дитячому віці пацієнтів з ентезит-асоційованим варіантом ЮІА встановлено, що групи пацієнтів не відрізнялися за наявністю HLA-B27 антигену, ревматоїдного фактора, А-ЦЦП, однак у пацієнтів з відсутніми суглобовими та позасуглобовими проявами виявлена вища лабораторна активність у дебюті захворювання $(p<0,05)$.

Таблиця 2. Аналіз клінічних проявів у пацієнтів з ентезит-асоційованим варіантом ЮІА в дитячому віці

\begin{tabular}{|c|c|c|c|c|c|c|}
\hline \multirow[b]{2}{*}{ Клінічні прояви } & \multicolumn{3}{|c|}{ Суглобові пошкодження } & \multicolumn{3}{|c|}{ Позасуглобові пошкодження } \\
\hline & відсутні (n=15) & $\begin{array}{l}\text { JADI-A } \geq 1 \\
(n=6)\end{array}$ & $\mathrm{P}$ & $\begin{array}{l}\text { відсутні } \\
(n=16)\end{array}$ & $\begin{array}{c}J A D I-E \geq 1 \\
(n=5)\end{array}$ & $\mathrm{p}$ \\
\hline Тривалість ранкової скутості & $35(10 ; 45)$ & $30(22 ; 112)$ & $>0,05$ & $30(30 ; 40)$ & $32(2,5 ; 82,5)$ & $>0,05$ \\
\hline $\begin{array}{l}\text { Наявність лімфаденопатії чи } \\
\text { спленомегалії в дебюті }\end{array}$ & $0(0 \%)$ & $0(0 \%)$ & $>0,05$ & $0(0 \%)$ & $0(0 \%)$ & $>0,05$ \\
\hline Артрит >3 суглобів в дитинстві & $9(60 \%)$ & $4(66,7 \%)$ & $>0,05$ & $4(25 \%)$ & $3(60 \%)$ & $<0,05$ \\
\hline $\begin{array}{l}\text { Наявність симетричного } \\
\text { артриту в де6юті }\end{array}$ & $5(33,3 \%)$ & $2(33,3 \%)$ & $>0,05$ & $4(25 \%)$ & $3(60 \%)$ & $<0,05$ \\
\hline $\begin{array}{l}\text { Наявність артриту кистей в } \\
\text { дебюті }\end{array}$ & $6(40 \%)$ & $2(33,3 \%)$ & $>0,05$ & $7(43,8 \%)$ & $1(20 \%)$ & $>0,05$ \\
\hline Наявність болю в хребті & $7(46,7 \%)$ & $3(50 \%)$ & $>0,05$ & $6(37,5 \%)$ & $4(80 \%)$ & $<0,05$ \\
\hline $\begin{array}{l}\text { Наявність болю в шийному } \\
\text { відділі хребта }\end{array}$ & $3(20 \%)$ & $1(16,7 \%)$ & $>0,05$ & $2(12,5 \%)$ & $2(40 \%)$ & $<0,05$ \\
\hline Наявність лихоманки & $4(26,7 \%)$ & $0(0 \%)$ & $<0,05$ & $3(18,8 \%)$ & $1(20 \%)$ & $>0,05$ \\
\hline Наявність шкірних висипань & $0(0 \%)$ & $0(0 \%)$ & $>0,05$ & $0(0 \%)$ & $0(0 \%)$ & $>0,05$ \\
\hline Наявність увеїту & $1(6,7 \%)$ & $1(16,7 \%)$ & $>0,05$ & $0(0 \%)$ & $2(40 \%)$ & $>0,05$ \\
\hline $\begin{array}{l}\text { Рентгенологічні зміни в } \\
\text { дитинстві }\end{array}$ & $0(0 \%)$ & $0(0 \%)$ & $>0,05$ & $0(0 \%)$ & $0(0 \%)$ & $>0,05$ \\
\hline Гепатомегалія & $1(6,7 \%)$ & $0(0 \%)$ & $>0,05$ & $1(6,3 \%)$ & $0(0 \%)$ & $>0,05$ \\
\hline Наявність ентезитів & $10(66,7 \%)$ & $4(66,7 \%)$ & $>0,05$ & $9(56,3 \%)$ & $5(100 \%)$ & $<0,05$ \\
\hline Наявність дактилітів & $10(66,7 \%)$ & $2(33,3 \%)$ & $<0,05$ & $10(62,5 \%)$ & $2(40 \%)$ & $>0,05$ \\
\hline ВАШ в дебюті ЮІА, мм & $56,0 \pm 17,1$ & $56,0 \pm 20,7$ & $>0,05$ & $58,4 \pm 17,7$ & $44,5 \pm 10,2$ & $<0,05$ \\
\hline $\begin{array}{l}\text { ВАШ на тлі лікування в } \\
\text { дитинстві, мм }\end{array}$ & $47,0 \pm 19,5$ & $54,0 \pm 20,7$ & $>0,05$ & $51,5 \pm 19,9$ & $35,0 \pm 7,1$ & $<0,05$ \\
\hline JADAS в дебюті ЮІА, бали & $13,1 \pm 7,6$ & $9,8 \pm 5,3$ & $<0,05$ & $12,9+7,0$ & $6,0+2,8$ & $<0,05$ \\
\hline
\end{tabular}


Огляди літератури, оригінальні дослідження, погляд на проблему

Таблиця 3. Аналіз лабораторних даних пацієнтів з ентезит-асоційованим варіантом ЮІА в дитячому віці

\begin{tabular}{|c|c|c|c|c|c|c|}
\hline \multirow[b]{2}{*}{ Лабораторні дані } & \multicolumn{3}{|c|}{ Суглобові пошкодження } & \multicolumn{3}{|c|}{ Позасуглобові пошкодження } \\
\hline & відсутні (n=15) & $\begin{array}{c}\text { JADI-A } \geq 1 \\
(n=6)\end{array}$ & $p$ & відсутні (n=16) & JADI-E $\geq 1(n=5)$ & $p$ \\
\hline $\begin{array}{l}\text { HLA-B27 позитивність } \\
\text { у дитячому віці }\end{array}$ & $\begin{array}{l}11(73,3 \%) / \text { у } \\
1 \text { не дослідж. }\end{array}$ & $\begin{array}{c}6 \text { (100 \%) / } \\
\text { у } 0 \text { не дослідж. }\end{array}$ & $>0,05$ & $\begin{array}{c}13 \text { (81,2 \%) / у } 0 \text { не } \\
\text { дослідж. }\end{array}$ & $\begin{array}{c}4 \text { (80 \%) / } \\
\text { у } 1 \text { не дослідж. }\end{array}$ & $>0,05$ \\
\hline $\begin{array}{l}\text { Наявність А-ЦЦП в } \\
\text { дебюті ЮІА }\end{array}$ & $\begin{array}{c}0 \text { (0 \%) / у } 5 \text { не } \\
\text { дослідж. }\end{array}$ & $\begin{array}{c}0 \text { (0\%) / у } 4 \text { не } \\
\text { дослідж. }\end{array}$ & $>0,05$ & $\begin{array}{c}0 \text { (0 \%) / у } 5 \text { не } \\
\text { дослідж. }\end{array}$ & $\begin{array}{c}0 \text { (0 \%) / у } 2 \text { не } \\
\text { дослідж. }\end{array}$ & $>0,05$ \\
\hline РФ (+) в дебюті ЮІА & $0(0 \%)$ & $0(0 \%)$ & - & $0(0 \%)$ & $0(0 \%)$ & - \\
\hline $\begin{array}{l}\text { ШОЕ в дебюті ЮІА, } \\
\text { мм/год }\end{array}$ & $33(16,5 ; 50,5)$ & $7(6,5 ; 45,5)$ & $<0,05$ & $36(14 ; 52)$ & $9,5(7 ; 19,5)$ & $<0,05$ \\
\hline $\begin{array}{l}\text { ШОЕ на тлі лікування } \\
\text { В дитинстві, мм/год }\end{array}$ & $7,5(4,2 ; 15,7)$ & $13(3 ; 14)$ & $>0,05$ & $7,5(4,2 ; 17,2)$ & $13(3 ; 14)$ & $>0,05$ \\
\hline $\begin{array}{l}\text { СРБ в дебюті } \\
\text { захворювання }\end{array}$ & $6(6 ; 9)$ & $12(9 ; 14)$ & $>0,05$ & $24(12 ; 26)$ & $6(6 ; 11)$ & $<0,05$ \\
\hline
\end{tabular}

Примітка. *Медіана (25 \% квартиль; 75 \% квартиль).

Пацієнти, в яких розвинулися суглобові пошкодження в дорослому віці, рідше отримували ГК, порівняно з пацієнтами без суглобових пошкоджень, однак за тривалістю прийому ГК та кумулятивною дозою вони не відрізнялися між собою (табл. 4). Також не виявлено достовірних відмінностей у цих групах пацієнтів за прийомом
БПРП, кількістю призначених БПРП та тривалістю їх прийому, як і наявністю ІБТ. Однак встановлено, що за характером клінічної картини, активністю захворювання, пацієнти з розвитком суглобових та позасуглобових пошкоджень частіше потребували інтенсифікації терапії як БПРП, так і ІБТ.

Таблиця 4. Аналіз проведеного лікування пацієнтів з ентезит-асоційованим варіантом ЮІА в дитячому віці

\begin{tabular}{|c|c|c|c|c|c|c|}
\hline \multirow[b]{2}{*}{ Лабораторні дані } & \multicolumn{3}{|c|}{ Суглобові пошкодження } & \multicolumn{3}{|c|}{ Позасуглобові пошкодження } \\
\hline & відсутні (n=15) & $\begin{array}{c}\text { JADI-A } \geq 1 \\
(n=6)\end{array}$ & $p$ & $\begin{array}{c}\text { відсутні } \\
(n=16)\end{array}$ & JADI-E $\geq 1 \quad(n=5)$ & $p$ \\
\hline Прийом ГК в дитинстві & $11(73,3 \%)$ & $3(50 \%)$ & $<0,05$ & $12(75 \%)$ & $2(40 \%)$ & $>0,05$ \\
\hline Кумулятивна доза ГК, г & $80(0 ; 1095)$ & $140(0 ; 3825)$ & $>0,05$ & $40(0 ; 1560)$ & $350(180 ; 7200)$ & $>0,05$ \\
\hline Тривалість прийому ГК, міс. & $1(0,3 ; 12)$ & $3,2(0,1 ; 37,5)$ & $>0,05$ & $1(0 ; 9)$ & $1(0,5 ; 30)$ & $>0,05$ \\
\hline $\begin{array}{l}\text { Прийом ГК на момент } \\
\text { огляду }\end{array}$ & $1(6,7 \%)$ & $0(0 \%)$ & $>0,05$ & $1(6,3 \%)$ & $0(0 \%)$ & $>0,05$ \\
\hline Тривалість БПРП, роки & $2(0,3 ; 6)$ & $5,5(2,5 ; 9,7)$ & $>0,05$ & $2,5(2 ; 4)$ & $2,5(0,5 ; 5,2)$ & $>0,05$ \\
\hline Відсутність БПРП & $2(13,3 \%)$ & $1(16,7 \%)$ & \multirow[t]{3}{*}{$>0,05$} & $2(12,5 \%)$ & $1(20,0 \%)$ & \multirow[t]{3}{*}{$>0,05$} \\
\hline Прийом 1 БПРП & $4(26,7 \%)$ & $1(16,7 \%)$ & & $5(31,2 \%)$ & $0(0 \%)$ & \\
\hline Прийом 2-х і більше БПРП & $9(60 \%)$ & $4(66,7 \%)$ & & $9(56,3 \%)$ & $4(80,0 \%)$ & \\
\hline Наявність ІБТ терапії раніше & $1(6,7 \%)$ & $1(16,7 \%)$ & $>0,05$ & $2(12,5 \%)$ & $0(0 \%)$ & $>0,05$ \\
\hline $\begin{array}{l}\text { Потреба в інтенсифікації } \\
\text { терапії }\end{array}$ & $5(33,3 \%)$ & $3(50 \%)$ & $<0,05$ & $3(18,7 \%)$ & $5(100 \%)$ & $<0,05$ \\
\hline
\end{tabular}

Примітка. БПРП - базисні протиревматичні препарати, ІБТ - імунобіологічна терапія, ГК - глюкокортикоїди.

Нами проведено аналіз клінічних проявів у пацієнтів з ентезит-асоційованим варіантом ЮІА в дорослому віці (табл. 5). Встановлено, що пацієнти з сулобовими пошкодженнями в дорослому віці частіше мали симетричне ураження суглобів (33,3 \% пацієнтів з суглобовими пошкодженнями проти 6,7\% без таких пошкоджень, p<0,05). Також виявлено, що у дорослому віці пацієнти з позасуглобовими проявами мали більш виражені рентгенологічні зміни, функціональну недостатність суглобів, тривалішу ранкову скутість та в них час- тіше виявляли симетричне ураження суглобів, лімфаденопатію, біль у хребті та вищу активність за JADAS, ніж у пацієнтів без розвитку позасуглобових пошкоджень.

Аналіз лабораторних даних у пацієнтів з ентезит-асоційованим варіантом ЮІА в дорослому віці (табл. 6) показав, що пацієнти з наявністю суглобових та позасуглобових пошкоджень мали вищі рівні СРБ $(p<0,05)$, а пацієнти з наявністю позасуглобових пошкоджень мали частіше позитивний АНФ. 
Огляди літератури, оригінальні дослідження, погляд на проблему

Таблиця 5. Аналіз клінічних проявів у пацієнтів з ентезит-асоційованим варіантом ЮІА в дорослому віці

\begin{tabular}{|c|c|c|c|c|c|c|}
\hline \multirow[b]{2}{*}{ Клінічні прояви } & \multicolumn{3}{|c|}{ Суглобові пошкодження } & \multicolumn{3}{|c|}{ Позасуглобові пошкодження } \\
\hline & $\begin{array}{c}\text { відсутні } \\
(n=15)\end{array}$ & $\begin{array}{c}\text { JADI-A } \geq 1 \\
(n=6)\end{array}$ & $p$ & $\begin{array}{c}\text { відсутні } \\
(n=16)\end{array}$ & $\begin{array}{c}J A D I-E \geq 1 \\
(n=5)\end{array}$ & $p$ \\
\hline $\begin{array}{l}\text { Рентгенологічна стадія у } \\
\text { дорослому віці: }\end{array}$ & & & & & & \\
\hline 0 & $4(26,7 \%)$ & $0(0 \%)$ & $>0,05$ & 4 & $0(0 \%)$ & $<0,05$ \\
\hline 1 & $6(40 \%)$ & $2(33,3 \%)$ & & 7 & $1(20 \%)$ & \\
\hline 2 & $4(26,7 \%)$ & $3(50 \%)$ & & $5(31,3 \%)$ & $2(40 \%)$ & \\
\hline 3 & $1(6,7 \%)$ & $0(0 \%)$ & & $0(0 \%)$ & $1(20 \%)$ & \\
\hline 4 & $0(0 \%)$ & $1(16,7 \%)$ & & $0(0 \%)$ & $1(20 \%)$ & \\
\hline ФНС у дорослому віці & & & & & & \\
\hline 0 & $5(33,3 \%)$ & $0(0 \%)$ & $>0,05$ & $5(31,3 \%)$ & $0(0 \%)$ & $<0,05$ \\
\hline 1 & $5(33,3 \%)$ & $3(50 \%)$ & & $6(37,5 \%)$ & $2(40 \%)$ & \\
\hline 2 & $4(26,7 \%)$ & $2(33,3 \%)$ & & $5(31,3 \%)$ & $1(20 \%)$ & \\
\hline 3 & $1(6,7 \%)$ & $1(16,7 \%)$ & & $0(0 \%)$ & $2(40 \%)$ & \\
\hline Наявність системних проявів & $0(0 \%)$ & $0(0 \%)$ & $>0,05$ & $0(0 \%)$ & $0(0 \%)$ & $>0,05$ \\
\hline Тривалість ранкової скутості & $10(5 ; 40)$ & $7,5(3,7 ; 37,5)$ & $>0,05$ & $5(5 ; 10)$ & $40(20 ; 50)$ & $<0,05$ \\
\hline Наявність поліартриту & $1(6,7 \%)$ & $1(16,7 \%)$ & $>0,05$ & $1(6,3 \%)$ & $1(20 \%)$ & $>0,05$ \\
\hline Наявність артриту кистей & $1(6,7 \%)$ & $0(0 \%)$ & $>0,05$ & $1(6,3 \%)$ & $0(0 \%)$ & $>0,05$ \\
\hline $\begin{array}{l}\text { Наявність симетричного } \\
\text { артриту }\end{array}$ & $1(6,7 \%)$ & $2(33,3 \%)$ & $<0,05$ & $0(0 \%)$ & $3(60 \%)$ & $<0,05$ \\
\hline $\begin{array}{l}\text { Наявність лімфаденопатії та/ } \\
\text { або спленомегалії }\end{array}$ & $0(0 \%)$ & $1(16,7 \%)$ & $>0,05$ & $0(0 \%)$ & $1(20 \%)$ & $<0,05$ \\
\hline Наявність шкірних висипань & $0(0 \%)$ & $0(0 \%)$ & $>0,05$ & $0(0 \%)$ & $0(0 \%)$ & $>0,05$ \\
\hline Наявність увеїту & $1(6,7 \%)$ & $1(16,7 \%)$ & $>0,05$ & $0(0 \%)$ & $2(40 \%)$ & $<0,05$ \\
\hline Наявність олігоартриту & $14(93,3 \%)$ & $5(83,3 \%)$ & $>0,05$ & $15(93,7 \%)$ & $4(80 \%)$ & $>0,05$ \\
\hline Наявність дактилітів & $2(13,3 \%)$ & $1(16,7 \%)$ & $>0,05$ & $2(12,5 \%)$ & $1(20 \%)$ & $>0,05$ \\
\hline Наявність болю в хребті & $8(53,3 \%)$ & $5(83,3 \%)$ & $>0,05$ & $8(50 \%)$ & $5(100 \%)$ & $<0,05$ \\
\hline Потреба в протезуванні & $0(0,0 \%)$ & $3(50 \%)$ & $<0,05$ & $4(25 \%)$ & $3(60 \%)$ & $>0,05$ \\
\hline Кількість болючих суглобів & $0,5(0 ; 3,5)$ & $3(1,5 ; 5,5)$ & $>0,05$ & $0(0 ; 2)$ & $5(4 ; 7,5)$ & $>0,05$ \\
\hline $\begin{array}{l}\text { Кількість деформованих } \\
\text { суглобів, анкілозів або протези }\end{array}$ & $0(0 ; 0)$ & $0(0 ; 1)$ & $>0,05$ & $0(0 ; 0)$ & $0,5(0 ; 1)$ & $>0,05$ \\
\hline Кількість припухлих суглобів & $0(0 ; 0)$ & $0(1,5 ; 2,5)$ & $>0,05$ & $0(0 ; 0)$ & $1(0,5 ; 2,5)$ & $>0,05$ \\
\hline ВАШ пацієнт & $30(8 ; 50)$ & $35(10 ; 62)$ & $>0,05$ & $10(8,5 ; 37,5)$ & $60(45 ; 71)$ & $<0,05$ \\
\hline JADAS, бали & $6,1 \pm 5,5$ & $10,8 \pm 9,1$ & $>0,05$ & $5,7 \pm 6,7$ & $12,8 \pm 74,8$ & $<0,05$ \\
\hline
\end{tabular}

Таблиця 6. Аналіз лабораторних даних у пацієнтів з ентезит-асоційованим варіантом ЮІА в дорослому віці

\begin{tabular}{|l|c|c|c|c|c|c|}
\hline \multirow{2}{*}{ Лабораторні дані } & \multicolumn{2}{|c|}{ Суглобові пошкодження } & \multicolumn{3}{c|}{ Позасуглобові пошкодження } \\
\cline { 2 - 7 } & відсутні $(n=15)$ & $\begin{array}{c}\text { JADI-A } \geq 1 \\
(n=6)\end{array}$ & $p$ & $\begin{array}{c}\text { відсутні } \\
(n=16)\end{array}$ & JADI-E $\geq 1(n=5)$ & P \\
\hline ШОЕ, мМ/год & $12(4 ; 35)$ & $24(4,5 ; 62)$ & $>0,05$ & $7(3,2 ; 32,7)$ & $30(20 ; 49,5)$ & $>0,05$ \\
\hline СРБ & $4(0 ; 24)$ & $44(1,7 ; 96)$ & $<0,05$ & $4(0,2 ; 19)$ & $24(14 ; 64)$ & $<0,05$ \\
\hline Наявність РФ & $0(0 \%)$ & $0(0 \%)$ & $>0,05$ & $0(0 \%)$ & $0(0 \%)$ & $>0,05$ \\
\hline Наявність А-ЦЦП & $0(0 \%)$ & $0(0 \%)$ & $>0,05$ & $0(0 \%)$ & $0(0 \%)$ & $>0,05$ \\
\hline Наявність АНФ & $1(6,7 \%)$ & $0(0 \%)$ & $>0,05$ & $0(0 \%)$ & $1(20 \%)$ & $<0,05$ \\
\hline
\end{tabular}

Примітка. ШОЕ - швидкість осідання еритроцитів; СРБ - С-реактивний білок; РФ - ревматоїдний фактор; А-ЦцП - антитіла до циклічного цитрулінового пептиду.

Методом розрахунку відношення шансів та довірчого інтервалу було відібрано ряд показників пацієнтів, які пов'язані з розвитком негативних наслідків ЮІА. Даний підхід дозволяє кількісно оцінити зв'язок між показниками та настанням неспри- ятливої події, а також з високою точністю обрати найбільш статистично значимі ознаки. Для розрахунку коефіцієнтів моделі на основі відібраних показників застосовано метод бінарної логістичної регресії. Таким методом було вибрано клінічні та 
Огляди літератури, оригінальні дослідження, погляд на проблему лабораторні фактори несприятливого прогнозу. Ниж- розвитку суглобових пошкоджень JADI-A (табл. 7) че наводимо результати аналізу факторів ризику та позасуглобових пошкоджень JADI-E (табл. 8).

Таблиця 7. Фактори ризику розвитку суглобових пошкоджень JADI-A ентезит-асоційованого варіанта ЮIA

\begin{tabular}{|l|c|c|c|c|c|c|}
\hline \multirow{2}{*}{\multicolumn{1}{|c|}{ Показники }} & \multicolumn{3}{c|}{ Уніваріантний аналіз } & \multicolumn{3}{c|}{ Мультиваріантний аналіз } \\
\cline { 2 - 6 } & OR & $95 \% \mathrm{Cl}$ & $\mathrm{P}$ & $\mathrm{OR}$ & $95 \% \mathrm{Cl}$ & $\mathrm{P}$ \\
\hline $\begin{array}{l}\text { Вік пацієнта на початку } \\
\text { захворювання, роки }\end{array}$ & 0,766 & $0,626-0,938$ & 0,010 & 0,476 & $0,125-0,891$ & 0,001 \\
\hline $\begin{array}{l}\text { Час відтермінування встановлення } \\
\text { діагнозу, міс }\end{array}$ & 1,028 & $1,011-1,045$ & 0,001 & 2,021 & $1,256-3,698$ & 0,001 \\
\hline Наявність дактилітів в дитинстві & 0,160 & $0,062-0,412$ & 0,001 & 0,194 & $0,011-0,893$ & 0,002 \\
\hline Наявність гарячки в дитинстві & 0,499 & $0,125-0,902$ & 0,001 & & & $\mathrm{NS}$ \\
\hline ШОЕ в дебюті захворювання & 0,883 & $0,562-0,905$ & 0,043 & & & $\mathrm{NS}$ \\
\hline Активність за ЈАDАS в дитинстві & 1,953 & $1,084-2,028$ & 0,003 & 2,541 & $1,924-6,996$ & 0,001 \\
\hline Прийом ГК & 0,182 & $0,061-0,540$ & 0,002 & 0,380 & $0,237-0,680$ & 0,041 \\
\hline Потреба в інтенсифікації терапії & 2,667 & $1,117-4,368$ & 0,027 & & & $\mathrm{NS}$ \\
\hline ІБТ & 3,444 & $1,696-5,648$ & 0,002 & & & $\mathrm{NS}$ \\
\hline
\end{tabular}

Таблиця 8. Фактори ризику розвитку позасуглобових пошкоджень (JADI-E) ентезит-асоційованого варіанта ЮIA

\begin{tabular}{|l|c|c|c|c|c|c|}
\hline \multirow{2}{*}{ Показники } & \multicolumn{3}{|c|}{ Уніваріантний аналіз } & \multicolumn{3}{c|}{ Мультиваріантний аналіз } \\
\cline { 2 - 6 } & $\mathrm{OR}$ & $95 \% \mathrm{Cl}$ & $\mathrm{P}$ & $\mathrm{OR}$ & $95 \% \mathrm{Cl}$ & $\mathrm{P}$ \\
\hline $\begin{array}{l}\text { Вік пацієнта на початку } \\
\text { захворювання, р. }\end{array}$ & 0,736 & $0,613-0,884$ & 0,011 & 0,124 & $0,074-0,243$ & 0,001 \\
\hline $\begin{array}{l}\text { Час відтермінування встановлення } \\
\text { діагнозу, міс. }\end{array}$ & 1,032 & $1,015-0,050$ & 0,001 & 3,021 & $1,512-9,123$ & 0,001 \\
\hline $\begin{array}{l}\text { Наявність симетричного артриту } \\
\text { в дитинстві }\end{array}$ & 7,200 & $2,742-18,905$ & 0,001 & 7,817 & $2,814-19,001$ & 0,001 \\
\hline $\begin{array}{l}\text { Наявність болю в хребті в } \\
\text { дитинстві }\end{array}$ & 7,333 & $2,896-18,571$ & 0,001 & 8,034 & $1,394-19,605$ & 0,001 \\
\hline $\begin{array}{l}\text { Наявність болю в шийному відділі } \\
\text { хребта в дитинстві }\end{array}$ & 5,001 & $1,768-14,144$ & 0,002 & & & $\mathrm{NS}$ \\
\hline ШОЕ в дебюті захворювання & 0,881 & $0,828-0,923$ & 0,002 & & & $\mathrm{NS}$ \\
\hline СРБ в дебюті захворювання & 0,775 & $0,678-0,885$ & 0,001 & & & $\mathrm{NS}$ \\
\hline ВАШ в дитинстві пацієнт & 0,836 & $0,744-0,938$ & 0,002 & & & $\mathrm{NS}$ \\
\hline ВАШ в дитинстві лікар & 0,912 & $0,849-0,980$ & 0,012 & & & $\mathrm{NS}$ \\
\hline Активність за ЈАDАS в дитинстві & 0,744 & $0,619-0,893$ & 0,002 & 0,341 & $0,231-0,657$ & 0,002 \\
\hline Потреба в інтенсифікації терапії & 1,605 & $1,003-1,839$ & 0,001 & 2,547 & $1,657-4,061$ & 0,003 \\
\hline
\end{tabular}

Як видно з таблиці 7, факторами ризику розвитку суглобових пошкоджень (JADI-A) ентезитасоційованого варіанту ЮІА $\epsilon$ вік пацієнта на початку захворювання, час відтермінування встановлення діагнозу, наявність у дитинстві дактилітів, гарячки, рівень ШОЕ в дебюті захворювання, активність за JADAS в дитинстві, прийом ГК, потреба в інтенсифікації терапії, прийом ІБТ. Показник наявності дактилітів у дитинстві не увійшов до таблиці 7 в зв'язку з неможливістю розрахувати показники відношення шансів для нульових категорій, однак був визнаний значним за попереднім аналізом. В таблиці 8 представлено фактори ризику розвитку позасуглобових пошкоджень (JADI-E) ентезит-асоційованого варіанту ЮІА, до яких входять вік пацієнта на початку захворювання, час відтермінування встановлення діагнозу, наявність в дитинстві симетричного артриту, болю в хребті та в його шийному відділі, рівні ШОЕ та СРБ в дебюті захворювання, оцінка загального стану за ВАШ у дитинстві пацієнтом та лікарем, активність за JADAS у дитинстві, потреба в інтенсифікації терапії.

При детальному аналізі результатів дослідження уніваріантного та мультиваріантного аналізу показників було відібрано найбільш вагомі фактори 3 математичної та медичної точок зору, на підставі яких розроблено математичну модель прогнозування ймовірності р виникнення віддалених негативних наслідків ентезит-асоційованого варіанта ЮІА у вигляді суглобових та позасуглобових уражень. 
Огляди літератури, оригінальні дослідження, погляд на проблему

Для аналізу суглобових уражень використовують значення

$$
z=\sum_{i=1}^{5} a_{i} \cdot x_{i}+C_{a}
$$
роки;

де $x_{1}$ - вік пацієнта на початку захворювання,

$x_{2}$ - час відтермінування діагнозу, міс.;

$x_{3}$ - наявність дактилітів в дитинстві (0 - "ні", 1 - "так");

$x_{4}$ - активність за JADAS в дитинстві, бали;

$x_{5}$ - прийом глюкокортикоїдів раніше (0 - "ні", 1 - "так");

$a_{1}, a_{2}, \ldots a_{5}$ - відповідні вагові коефіцієнти для показників суглобових уражень;

$C_{a}$ - константа, яка враховує суглобові ураження.

Для прогнозування віддалених наслідків позасуглобових уражень ентезит-асоційованого варіанта ЮІА використовують наступну формулу:

$$
z=\sum_{j=1}^{6} b_{j} \cdot y_{j}+C_{e}
$$
роки;

де $y_{1}$ - вік пацієнта на початку захворювання,

$y_{2}$ - час відтермінування діагнозу, міс.;

$y_{3}$ - наявність симетричного артриту в дитинстві (0 - "ні", 1 - "так");

$y_{4}$ - наявність болю в хребті в дитинстві $(0-$ "ні", 1 - "так");

$y_{5}$ - активність за JADAS в дитинстві, бали;

$b_{1}$ - потреба в інтенсифікації терапії (0 - "ні", 1 - "так");

$b_{1}, b_{2}, \ldots b_{6}$ - відповідні вагові коефіцієнти для показників позасуглобових уражень;

Сe - константа, яка враховує позасуглобові ураження.

Для розрахунку ймовірності виникнення суглобових уражень (JADI-A) ентезит-асоційованого варіанта ЮІА показник $z$ вираховується за формулою:

$z=-0,543 \cdot 15-0,009 \cdot 60-3,544 \cdot 0+0,095 \cdot 6-$ $-2,766 \cdot 0+9,359=21,244$.

Для розрахунку ймовірності виникнення позасуглобових уражень (JADI-E) ентезит-асоційованого варіанта ЮІА показник $z$ вираховується за формулою:

$z=-4,857 \cdot y_{1}+0,062 \cdot y_{2}+1,305 \cdot y_{3}+$

$+5,499 \cdot y_{4}-3,033 \cdot y_{5}+33,146 \cdot y_{6}+47,768$.

Для прогнозування негативних віддалених наслідків ентезит-асоційованого варіанта ЮІА у дорослому віці на практиці спочатку проводять клінічний огляд пацієнта. При виявленні ентезит- асоційованого варіанта ЮІА оцінюють наявність факторів ризику, таких як вік пацієнта на початку захворювання, час відтермінування встановлення діагнозу, наявність в дитинстві дактилітів, симетричного артриту, болю в хребті, активність за JADAS в дитинстві, прийом глюкокортикоїдів, потреба в інтенсифікації терапії. Після цього виявлені фактори ризику підставляють у відповідні формули віддалених суглобових та позасуглобових наслідків ентезит-асоційованого варіанта ювенільного ідіопатичного артриту та оцінюють імовірність їх виникнення. Значення $р$ в межах від 0 до 0,4 свідчить про низький ризик настання несприятливої події, значення $р$ від 0,41 до 0,6 - про середній ризик, і в свою чергу, при $р$ від 0,61 до 1 - про високий ризик. При виявленні середнього чи високого ризику проводять корекцію терапії та рекомендують більш інтенсивне спостереження за пацієнтом.

Використання запропонованої моделі може бути проілюстроване такими прикладами.

Приклад 1. Пацієнт Г., діагноз ЮІА, ентезитасоційований варіант. Захворювання дебютувало у віці 15 років, діагноз встановлено через 60 місяців від початку перших клінічних проявів, без симетричного артриту, без дактилітів, без болю в шийному відділі хребта, активність за JADAS=6 балів, не приймав глюкокортикоїди та не було необхідності в інтенсифікації терапії.

Розрахунок ризику розвитку суглобових пошкоджень:

$$
z=-0,543 \cdot 15-0,009 \cdot 60-3,544 \cdot 0+0,095 \cdot 6-
$$$$
-2,766 \cdot 0+9,359=21,244 \text {, }
$$

$$
p=\frac{1}{1+e^{-21,244}} \approx 0,977 \rightarrow 1 .
$$

Розрахунок ризику розвитку позасуглобових пошкоджень:

$z=-4,857 \cdot 15+0,062 \cdot 60+1,305 \cdot 0+5,499 \cdot 0-$ $-3,033 \cdot 6+33,146 \cdot 0+47,768=-39,568$,

$$
p=\frac{1}{1+e^{39,568}} \approx 0,001 \rightarrow 0 .
$$

Прогнозований ризик розвитку віддалених суглобових наслідків JADI-A становить 97,7 \%, позасуглобових наслідків JADI-E становить 0,1 \%.

Результат збігається з клінічним спостереженням, оскільки в пацієнта розвинувся анкілоз правого кульшового суглоба, що відповідає JADI-A $=1$, однак позасуглобові пошкодження у пацієнта не розвинулися, що відповідає JADI-E=0.

Приклад 2. Пацієнт О., діагноз ЮІА, ентезитасоційований варіант. Захворювання дебютувало 
Огляди літератури, оригінальні дослідження, погляд на проблему

у віці 13 років. Діагноз встановлено через 2 місяці після дебюту перших клінічних проявів, хвороба проявлялася симетричним артритом, з дактилітами, з болем в шийному відділі хребта. Пацієнт раніше не приймав глюкокортикоїдів, однак була необхідність в інтенсифікації терапії, активність за JADAS=4 бали.

Розрахунок ймовірності виникнення суглобових уражень (JADI-A):

$$
\begin{aligned}
& z=-0,543 \cdot 13-0,009 \cdot 60-3,544 \cdot 1+0,095 \cdot 4- \\
& -2,766 \cdot 0+9,359=-1,404
\end{aligned}
$$

$$
p=\frac{1}{1+e^{1,404}} \approx 0,197 .
$$

Розрахунок ймовірності виникнення позасуглобових уражень (JADI-E):

$$
\begin{gathered}
z=-4,857 \cdot 13+0,062 \cdot 60+1,305 \cdot 1+5,499 \cdot 1- \\
-3,033 \cdot 4+33,146 \cdot 1+47,768=16,165, \\
p=\frac{1}{1+e^{-16,165}} \approx 0,999 \rightarrow 1 .
\end{gathered}
$$

Прогнозований ризик розвитку віддалених суглобових наслідків JADI-A становить 1,9\%, позасуглобових наслідків JADI-E - $100 \%$. Цей результат збігається з нашим клінічним спостереженням, оскільки у хворого О. в дорослому віці не розвинулися значні суглобові пошкодження, однак виникли прояви позасугловових пошкоджень у вигляді катаракти та остеопорозу.

Результати й обговорення. В 2005 році група авторів на чолі з S. Viola запропонували систему оцінки в балах [2] суглобових та позасуглобових пошкоджень ЮІА за спеціальними індексами JADI (від англ. Juvenile Arthritis Damage Index). Суглобові пошкодження (JADI-A від англ. Articular) рекомендовано оцінювати у дорослих з ЮІА за сумою балів, що підраховуються за наявності значних функціональних порушень чи розвитку анкілозів або наявності протезів, у певних суглобах. Позасуглобові пошкодження (JADI-E від англ. Extra Articular) у дорослому віці оцінюють у балах з урахуванням уражень очей, м'язово-скелетної системи, шкірних покривів, ендокринної системи та розвитку амілоїдозу. Цей метод дозволяє не лише констатувати наявність уже сформованих негативних наслідків у дорослих, які хворіють 3 дитячого віку на ЮІА, а й кількісно їх оцінити. Однак він не враховує наявність в дитячому віці факторів ризику розвитку суглобових та позасуглобових пошкоджень, а за його допомогою неможливо спрогнозувати розвиток цих пошкоджень. За результатами досліджень Омельченко Л. І. та ін. [3] розроблено спосіб прогнозування перебігу ювенільного ревматоїдного артриту, який здійс- нюють на підставі аналізу клінічних та лабораторних показників у дебюті захворювання з подальшим обчисленням ймовірності несприятливого перебігу ЮРА. Цей спосіб полягає в прогнозуванні перебігу ЮРА на підставі аналізу таких факторів як ранній вік початку захворювання, розвиток поліартритичного суглобового синдрому за перші 6-8 місяців хвороби, обтяжена ревматичними захворюваннями спадковість, ступінь активності захворювання в дебюті захворювання, поліартритичний синдром в дебюті, ураження хребта в дебюті, розвиток функціональної недостатності в 6-8 місяців хвороби, стійко підвищені показники ШОЕ, С-реактивного білка, альфа-2-глобуліну. Цей спосіб має таку перевагу як оцінка прогнозування перебігу ЮІА на ранньому етапі хвороби з врахуванням клінічних та лабораторних факторів ризику. Однак, на відміну від нашого дослідження, за допомогою цього методу неможливо спрогнозувати перебіг різних варіантів ЮІА, зокрема, ентезит-асоційованого варіанта. Також цей спосіб не дає можливості прогнозування віддалених наслідків ЮІА в дорослому віці, зокрема розвитку суглобових та позасуглобових пошкоджень. У 2014 р. Я. Є. Бойко та співавтори [4] запропонували спосіб прогнозування ризику формування рефрактерного перебігу ювенільного ревматоїдного артриту залежно від варіанта хвороби, активності, кількості несприятливих факторів та цитокінових маркерів несприятливого перебігу. Однак наш спосіб відрізняється тим, що використовуються прості клінічні та лабораторні маркери, які $\epsilon$ доступними та не потребують спеціальних цитокінових лабораторних досліджень. За допомогою запропонованого нами методу можна прогнозувати розвиток суглобових та позасуглобових пошкоджень. У нашій попередній роботі [5] ми оцінювали віддалені наслідки ЮІА залежно від наявності HLA-B 27, AНФ та РФ, однак не вивчали фактори ризику розвитку віддалених наслідків у дорослому віці при різних варіантах ЮІА.

Однак наша робота має деякі обмеження, оскільки в дослідження включена невелика група пацієнтів з ентезит-асоційованим варіантом ЮІА. Це захворювання, згідно з наказом МОЗ (№ 919 від 30.12.2015 та № 731 від 29.06.2017), внесено до переліку рідкісних (орфанних) захворювань, що обмежує спостереження за такими пацієнтами в дорослому віці та потребує створення всеукраїнського реєстру пацієнтів з ЮІА в дорослому віці, незалежно від прийому ІБТ, для проведення оцінки стану та призначеної терапії і ії ефективності. Тому створення та ведення державного реєстру громадян, які страждають на рідкісні (орфанні) захворювання, $\epsilon$ необхідним. Однак на сьогодні порядок ведення такого реєстру 
Огляди літератури, оригінальні дослідження, погляд на проблему

не затверджено, як і перелік та обсяг ліків для терапії рідкісних захворювань.

Висновки. 1. Факторами ризику розвитку суглобових та позасуглобових пошкоджень у дорослому віці в пацієнтів з ентезит-асоційованим варіантом ЮІА $\epsilon$ вік пацієнта на початку захворювання, час відтермінування встановлення діагнозу, наявність у дитинстві дактилітів, симетричного артриту, болю в хребті, активність за JADAS в дитинстві, прийом глюкокортикоїдів, потреба в інтенсифікації терапії.

\section{ЛІТЕРАТУРА}

1. International League of Associations for Rheumatology classification of juvenile idiopathic arthritis: second revision, Edmonton 2001. / R. E. Petty, T. R. Southwood, P. Manners [et al.] // J. Rheumatol. - 2004. - No. 31. - P. 390-392.

2. Development and validation of a clinical index for assessment of long-term damage in juvenile idiopathic arthritis / S. Viola, E. Felici, S. Magni-Manzoni [et al.] // Arthritis Rheum. - 2005. - No. 52. - P. 2092-2102.

3. Омельченко Л. І., Дудка І. В., Онищенко О. Ю. Спосіб прогнозування перебігу ювенільного ревматоїдного артриту. - Патент України на винахід № 43536 (деклараційний), МПК А61В 10/00. - Заявл. № 2001010384 від 18.01.2001 р. - Опубл. 17.12.2001 р., бюл. № 11.

\section{REFERENCES}

1. Petty, R.E., Southwood, T.R., Manners, P., Baum, J., Glass, D.N., Goldenberg, J., et al. (2004). International League of Associations for Rheumatology classification of juvenile idiopathic arthritis: second revision, Edmonton 2001. J. Rheumatol., 31, 390-392.

2. Viola, S., Felici, E., Magni-Manzoni, S., Pistorio, A., Buoncompagni, A., Ruperto, N., et al. (2005). Development and validation of a clinical index for assessment of longterm damage in juvenile idiopathic arthritis. Arthritis Rheum., 52, 2092-2102.

3. Omelchenko, L.I., Dudka, I.V., Onyshchenko, O.Yu. (2001). Sposib prohnozuvannia perebihu yuvenilnoho revmatoidnoho artrytu [A method for predicting the course of juvenile rheumatoid arthritis]. Patent of Ukraine for invention №43536, application №2001010384, bulletin №11 [in Ukrainian].

4. Boiko, Ya.le., Omelchenko, L.I., \& Chernyshov, V.P. (2014). Prohnozuvannia ryzyku formuvannia refrakternoho
2. Розроблено прогностичну модель розвитку суглобових та позасуглобових пошкоджень у дорослому віці в пацієнтів з ентезит-асоційованим варіантом ЮІА. Заявлений спосіб прогнозування віддалених наслідків ентезит-асоційованого варіанта ЮІА у дорослому віці $\epsilon$ ефективним, що дозволяє визначити несприятливий перебіг захворювання та може стати основою для персоніфікованого лікування для запобігання розвитку значних суглобових та позасуглобових пошкоджень внаслідок ЮІА у дорослому віці.

4. Бойко Я. Є. Прогнозування ризику формування рефрактерного перебігу ювенільного ревматоїдного артриту залежно від варіанта хвороби, активності, кількості несприятливих факторів та цитокінових маркерів несприятливого перебігу / Я. Є. Бойко, Л. І. Омельченко, В. П. Чернишов // Укр. ревматолог. журнал. - 2014. № 58 (4). - С. 50-54

5. Віддалені наслідки суглобових та позасуглобових пошкоджень у дорослих хворих з ювенільним ревматоїдним артритом з різними імуногенетичними маркерами / М. Б. Джус, Г. В. Мостбауер, Т. А. Карасевська, О. І. Івашківський // Галицький лікарський вісник. 2017. - № 24 (3). - С. 7-11.

perebihu yuvenilnoho revmatoidnoho artrytu zalezhno vid varianta khvoroby, aktyvnosti, kilkosti nespryiatlyvykh faktoriv ta tsytokinovykh markeriv nespryiatlyvoho perebihu [Prediction of the risk of formation of refractory flow of juvenile rheumatoid arthritis depending on the variant of disease, activity, number of adverse factors and cytokine markers of unfavorable course]. Ukr. Revmatoloh. zhurnal - Ukrainian Rheum. Journal, 58(4), 50-54 [in Ukrainian].

5. Dzhus, M.B., Mostbauer, H.V., Karasevska, T.A., Ivashkivskyi, O.I. (2017). Viddaleni naslidky suhlobovykh ta pozasuhlobovykh poshkodzhen u doroslykh khvorykh z yuvenilnym revmatoidnym artrytom z riznymy imunohenetychnymy markeramy [Long-term effects of articular and extra-articular damage in adult patients with juvenile rheumatoid arthritis with different immunogenic markers]. Halytskyi likarskyi visnyk - Galician Medicinal Herald, 24 (3), 7-11 [in Ukrainian]. 


\title{
Огляди літератури, оригінальні дослідження, погляд на проблему ПРОГНОЗИРОВАНИЕ ОТДАЛЕННЫХ ПОСЛЕДСТВИЙ ЕНТЕЗИТ-АССОЦИИРОВАННОГО ВАРИАНТА ЮВЕНИЛЬНОГО ИДИОПАТИЧЕСКОГО АРТРИТА
}

\author{
○М. Б. Джус ${ }^{1}$, Т. В. Марушка', О. К. Носовец² \\ Национальный медицинский университет имени А. А. Богомольца, г. Киев ${ }^{1}$ \\ Национальный технический университет Украины «Киевский политехнический институт \\ имени Игоря Сикорского», г. Киев ${ }^{2}$
}

РЕЗЮМЕ. Известно, что ентезит-ассоциированный вариант ювенильного идиопатического артрита (ЮИА) В ряде случаев может приводить к развитию значительных как внесуставных, так и суставных повреждений. Преимущественно поражаются тазобедренные и коленные суставы с ограничением их функции и развитием анкилоза, что требует проведения операционного вмешательства у этих пациентов; также часто развиваются катаракта и слепота из-за поражения глаз в детском возрасте.

Цель - оценить факторы риска развития во взрослом возрасте суставных и внесуставных повреждений при ентезит-ассоциированном варианте ЮИА и разработать прогностическую модель их развития.

Материал и методы. В исследование включен 21 взрослый пациент с ентезит-ассоциированным вариантом ЮИА. Ретроспективно проанализированы медицинская документация пациентов с ентезит-ассоциированным вариантом ЮИА, с учетом клинических проявлений в дебюте заболевания, лабораторных показателей и ответа на проводимую терапию. Во взрослом возрасте для оценки ЮИА использовали интегральный индекс повреждения суставных (JADI-A) и внесуставных (JADI-E) поражений.

Результаты. Методом бинарной логистической регрессии выявлены факторы неблагоприятного прогноза и разработана математическая модель прогнозирования вероятности возникновения отдаленных негативных последствий ентезит-ассоциированного ЮИА в виде суставных и внесуставных поражений.

Выводы. 1. Факторами риска развития суставных и внесуставных повреждений во взрослом возрасте у пациентов с ентезит-ассоциированным вариантом ЮИА являются возраст пациента в начале заболевания, время отсрочки установления диагноза, наличие в детстве дактилита, симметричного артрита, боли в позвоночнике, активность по JADAS в детстве, прием глюкокортикоидов, потребность в интенсификации терапии. 2. Разработана прогностическая модель развития суставных и внесуставных повреждений во взрослом возрасте у пациентов с ентезит-ассоциированным вариантом ЮИА. Заявленный способ прогнозирования отдаленных последствий ентезит-ассоциированного варианта ЮИА во взрослом возрасте является эффективным, что позволяет определить неблагоприятное течение заболевания и может стать основой для персонифицированного лечения с целью предотвращения развития значительных суставных и внесуставных повреждений вследствие ЮИА во взрослом возрасте.

КЛЮЧЕВЫЕ СЛОВА: Ювенильный идиопатический артрит; ентезит-ассоциированный вариант; взрослые; прогноз; отдалённые последствия; JADI.

\section{PREDICTION OF LONG-TERM EFFECTS OF ENTHESITIS-ASSOCIATED VARIANT OF JUVENILE IDIOPATHIC ARTHRITIS}

\author{
@M. B. Dzhus' ${ }^{1}$ T. V. Marushko'1, O. K. Nosovets ${ }^{2}$ \\ O. O. Bohomolets National Medical University' \\ National Technical University of Ukraine "Ihor Sikorskyi Kyiv Polytechnic Institute"2
}

SUMMARY. It is known that the enthesitis-associated variant of JIA, in some cases, can lead to significant development of both extra-articular and articular damages. Predominantly hip and knee joints are affected with limitation of their function and the development of ankylosis, requiring surgical intervention in these patients, as well as cataracts and blindness often developed due to uveitis in childhood.

The aim of the study was to evaluate the risk factors of articular and extra-articular damages in adults with the enthesitis-associated variant of the JIA and to work out a prognostic model for their development.

Material and Methods. The study included 45 adult patients with enthesitis-associated variant of the JIA. Retrospective analysis of medical records of patients with enthesitis-associated variant of JIA was made, taking into account clinical manifestations in the onset of the disease, laboratory parameters and response to therapy. In adulthood, the integral index of articular (JADI-A) and extra-articular (JADI-E) damages was used to assess the long-term effects of JIA.

Results. Unfavorable prognostic factors were revealed by method of binary logistic regression. Mathematical model for predicting the probability of long-term negative articular and extra-articular damages of poly-articular JIA was developed.

Conclusions. 1. The risk factors for the development of articular and extra-articular damages in adulthood in patients with the enthesitis-associated variant of the JIA are the patient's age at the onset of the disease, the delay in diagnosis, the presence of dactylitis in childhood, symmetrical arthritis, spinal pain, JADAS activity in childhood, the history of glucocorticoids intake, need for intensified therapy. 2. A prognostic model for the development of articular and extra-articular damages in adult patients with an enthesitis-associated variant of the JIA has been developed. This model is effective and allows determine the adverse course of the disease and can be the basis for personalized treatment for the prevention of the development of significant articular and extra-articular damages of JIA.

KEY WORDS: juvenile idiopathic arthritis; enthesitis-associated variant; adults; prognosis; long term damages; JADI.

Отримано 15.02.2018 